\title{
Overview of the Oportunistic Claiming Credit Card: Consumer Versus Company
}

\author{
W Krisnawati \\ Department of Management, University Muhammadiyah Gresik, Gresik, East Java, 61121, Indonesia \\ *Corresponding author email: wentikrisnawati@umg.ac.id
}

\begin{abstract}
Credit cards are now part of the lifestyle of urban people. There are not many complaints that come. Complaints from business or individual customers are of course something that must be avoided. If the complaint is present in the middle of running a business, it is feared that it will make the business reputation worse. The purpose of this study is to find out various reasons for complaints that come from opportunistic customers and the accuracy of employees handling opportunistic consumers who always try to justify the complaints they give and want to get fair feedback from the company without knowing the truth of the existing problems. The Methode for this research a qualitative phenomenological approach with 8 informants, namely credit card holders and employees of PT Bank XYZ. The validity of the data by triangulation, namely the source. The Results show Customer complaints on PT Bank XYZ credit cards are usually due to problems or complaints such as: delays in sending billing bills, cases of disputes or bills that have never been made by the customer, Research helps companies to be alert and alert to opportunity claimers, because complaints that deliberately take advantage of circumstances caused by bank officers' negligence can cause losses to the bank. The conclusion if the error that has occurred is the fault of the bank, the company will gracefully apologize to the customer and try to prevent the mistake from being repeated
\end{abstract}

Keyword: opportunistic consumers, handling complaints, banking

\section{INTRODUCTION}

The implementation of marketing strategies within a company is always changing in line with developments and changes in the existing industrial environment. These changes force the company to continue to adapt to developments in the surrounding environment. Strategies are created to be able to win the competition by offering a clear concept of the product and the distinctive advantages it contains. Service companies currently emphasize more on the concept of marketing by approaching their customers, companies pay attention to how important customer satisfaction is for the survival of their companies in the long term. [1] Companies pay attention to this element of customer satisfaction as the basis for building consumer loyalty to the products or services it creates (Infobank, January 2008).

[2] Consumer complaining behavior (CCB) is a broad conceptual umbrella that includes a wide range of possible responses to unsatisfactory consumption situations (Istanbulluoglu, Leek, \& Szmigin, 2017). [3] Viewed from this perspective, the consumer's complaining behavior is changed from a discrete response to a dynamic process (Tronvoll, 2012). Increasingly tighter competition in the banking industry encourages the banking industry to quickly adjust to the developing needs and wants and demands of the surrounding community regarding banking products. This is indicated by the increasing expansion of foreign banks trying to enter the banking market in Indonesia. [1] The banking industry is currently competing to improve services to customers by providing facilities that make it easier for customers to carry out various financial transactions (Infobank, April 2008). One example is the application of eBanking or the ease of making transactions by indirectly coming to the bank, for example via SMS banking, namely transactions using the Short Message Service (SMS) facility or also conducting financial transactions via the internet, even transactions using credit cards.

Credit cards are a means of payment in lieu of cash that consumers can use to exchange for goods and services they want at places that accept credit cards (merchants). The definition of credit card in article 1 number 4 Bank Indonesia Regulation Number 7/52 / PBI / 2005 as amended by Bank Indonesia Regulation Number 10/8 / PBI / 2008 concerning the Implementation of Card-Based Payment Instrument Activities, namely:

Credit Cards are Payment Instruments by Using a Card that can be used to make payments for obligations arising from an economic activity, including spending transactions and / or to make cash withdrawals where the cardholder's payment obligations are fulfilled in advance by the acquirer or issuer, and the cardholder is obliged to pay off the 
payment obligations. At the agreed time both at once (charge card) or in installments.

Number of credit cards circulating in Indonesia seems to be still increasing amid the spread of the corona virus. Even so, the growth did not reach double digits. Based on Bank Indonesia (BI) data, the number of credit cards in circulation in February was recorded at 17.61 million cards. That number is up 2.67 percent compared to February 2019 which amounted to IDR 17.15 million cards. However, credit card transactions look almost stagnant. The total is only IDR 25.86 trillion or slightly up 0.19 percent from the previous IDR 25.81 trillion.

Total credit card transactions throughout February 2020 consisted of spending of IDR 25 trillion and the rest in cash of IDR 865.43 billion. If viewed historically, credit card users have indeed made more shopping transactions than cash. Total credit card transactions throughout February 2020 consisted of spending of IDR 25 trillion and the rest in cash of IDR 865.43 billion. [4] If viewed historically, credit card users actually do more shopping than cash (www.cnnindoenesia.com)

Leaders Card center also realize that to be able to compete in seizing the market, this large market potential will not produce optimal results without being accompanied by effective marketing strategy of each publishing company. Because of this, it appears that issuing companies - both banking and finance companies - are competing to implement a number of accurate strategies in order to survive and further expand their market share. Among a number of strategies currently implemented by issuing companies, they seem to be increasingly selective in maintaining the types of credit cards that the market likes and needs, competing to spoil consumers with various high-tech facilities and services, and trying to launch new credit card products that are innovative and in demand by the market.

Apart from the conveniences offered by the bank, there were not a few complaints that came. Complaints from business customers, of course, are things that must be avoided. If the complaint is present in the middle of running a business, it is feared that it will make the business reputation worse. For this reason, in running a business, it is also necessary to anticipate how consumers do not complain about the business both in terms of product quality, product quantity, and services of the business being run. If you find complaints that arise from consumers, of course you have to find the cause of these complaints. The ability to identify the reasons for the emergence of these complaints can be used as an evaluation step to improve the next business. Despite efforts to produce a constructive voice that is firmly directed, the complaint and review website remains flooded with negative stories about the company).

[5] Complaints are a sign of dissatisfaction. If this is not followed up, customers will move to other suppliers and / or brands of products or services, participate in word of mouth negative (WoM), or make complaints to organizations / third parties (Lam \& Dale, 1999; Davidow, 2000).

Several reasons why doing this research is because, many complaints have occurred in banks, especially in the credit card division. After conducting a mini research at the beginning before conducting interviews and observations at 3 banks in Surabaya, it was found that the existing problems were related to the increasing number of opportunist claiming actors.

\section{LITERATUR REVIEW}

\subsection{Customer Opportunistic}

[6] According to Mukherjee and Nath (2003) Opportunistic behavior is defined as a search for the possibility of someone being ripped off when making a transaction. Opportunistic behavior also has the meaning of behavior that tries to achieve its desires by all means even though it is illegal, which can lead to principal-agent relationships that occur in a contract eventually leading to adverse selection (hiding information) and moral hazard (abuse of authority).

[7] Opportunistic behavior can be defined as deceptively seeking self-interest (cf, Ping 1993), taking advantage of opportunities that arise, exploiting few opportunities regarding principles or consequences (Merriam-Webster Dictionary Online), and as taking advantage, often doing unethical things, from every situation and take advantage of these circumstances (The Free Dictionary.com)

\subsection{Complaints (Complain)}

[8] Complaints are one part of negative expression that results from the inconsistency between reality and someone's wishes (Simon \& James 2006, p.20). [9] A complaint is an action taken by someone, which includes communicating something negative about a product or service that is made or marketed (Oxford pocket dictionary, new edition, 2005). [8] According to Bell and Luddington (2006), customer complaints are feedback (feedback) from customers addressed to companies that is negative. This feedback can be done in writing or orally. [10] The 
problem that is often complained about, according to Bell and Luddington (2006), customer complaints are usually due to problems such as weak responsibility (responsiveness), weak help from company staff (helpfulness),product availability, shop policy / company (store policy), as well as service recovery.

\subsection{Types of Complain}

[11] According to Kotler (2003: 59) there are several types of complaints, namely: Complaints that are delivered verbally by telephone and direct communication. Complaints submitted in writing via the guest complain form.

[12] According Endar Sugirto (1999), customer complaints can be categorized or grouped into four, namely:

1. Mechanical Complaint (Complaint mechanical) Mechanical Complaint is a complaint from a customer in connection with the nonfunctioning of the equipment purchased or delivered to the customer. Or in other words, the products or outputs of the services provided are not as expected. This can happen because of damage or quality is not optimal.

2. Attitudinal Complaint (Complaints due to service staff attitude) Attitudinal

Complaint Is a customer complaint that arises because of the negative attitude of service officers when serving customers. This can be felt by customers through the indifference of service officers towards customers.

3. Service Related Complaint (Complaints related to service)
Service Related Complaint is a customer complaint due to matters related to the service itself. For example, if someone registers to take part in a competition, it turns out that the registration form is not ready and the officer is asked to wait.Í

4. Unusual Complaint (strange complaint) unusual Unusual Complaint is a customer complaint which for the officer is an oddity (unnatural/). Customers who complain like this are usually psychologically people whose lives are unhappy or lonely.

\subsection{Customer Opportunistic}

[13] According to [15] Opportunistic behavior is defined as a search for the possibility of someone being ripped off when making a transaction. Opportunistic behavior also has the meaning of behavior that tries to achieve its desires by all means even though it is illegal, which can lead to principalagent relationships that occur in a contract eventually leading to adverse selection (hiding information) and moral hazard (abuse of authority).

[14] Opportunistic behavior can be defined as deceptively seeking self-interest (cf, Ping 1993), taking advantage of opportunities that arise, exploiting few opportunities regarding principles or consequences (Merriam-Webster Dictionary Online), and as taking advantage, often doing unethical matters, from every situation and take advantage of these circumstances (The Free Dictionary.com) 


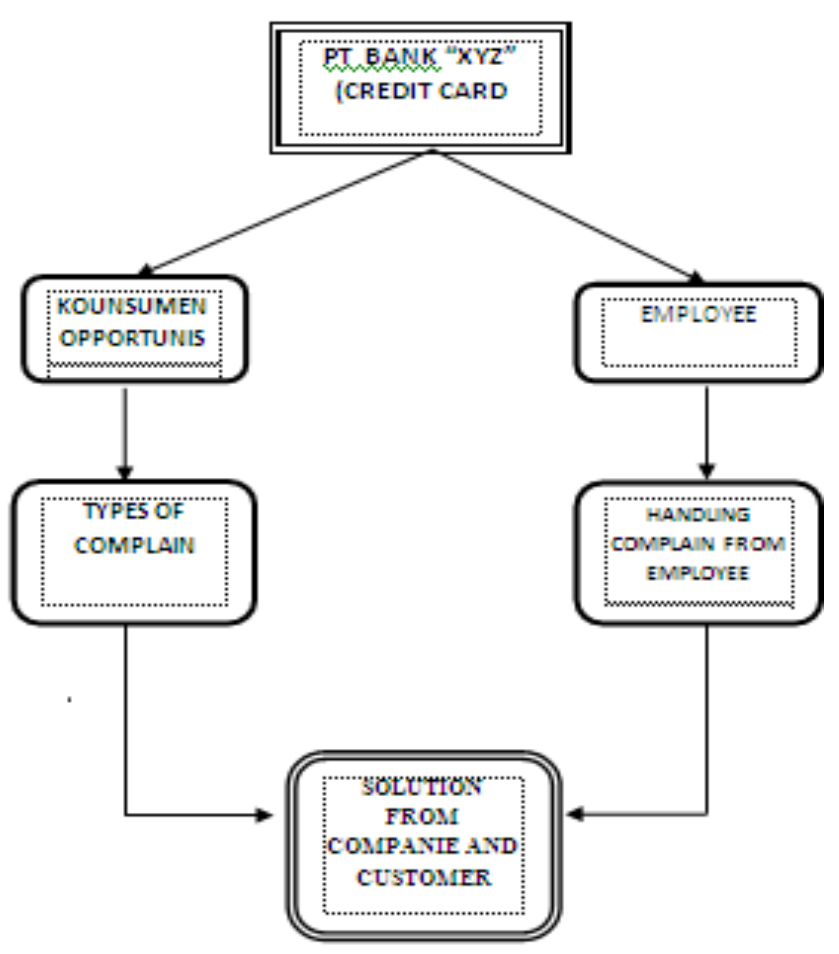

Figure 1. Research stages

\section{METHOD}

[15] This research is more focused on a qualitative approach with a case study methodology [17]. Case studies are also a more appropriate strategy if the main question of this research is how or why. If the researcher has little opportunity to control the events to be investigated and if the focus of the research objective lies on contemporary (current) phenomena in the context of real life. [15] In addition, case studies are more desirable to track contemporary events, if those events are concerned cannot be manipulated [17] research design Research design is an action plan to go from here to there, where " here 'can also be interpreted as a series of initial questions that must be answered, and is a series of conclusions (answers) about the question.

\subsection{Informant Data Informants}

Are a source of information or people used to provide information about research problems. To determine or select good informants at least there are several criteria that must be considered. Criteria for good informants are as following:

- Long and intensive with the information they will provide.

- 2. Still fully involved or have been fully involved in the activities that are informed.

- Have sufficient time to provide information.
- They are not conditioned or engineered in providing information.

- They are ready to provide the information.

Based on the description above, the parties who will be used as informants in this study are:

$\checkmark 4$ Informants (credit card users for more than 5 years)

$\checkmark \quad 4$ Employees of PT Bank XYZ(Customer Service and Team Leader in the billing section and working in the Card section) Center)

\subsection{Data retrieval}

This data is obtained by making direct observations, archival recordings and in-depth direct interviews with related parties in the company. Secondary data can be obtained from third parties, namely documentation from internet access and studying literatures and readings related to problems in research.

\subsection{Data analysis}

- Reduction Data

Process of sorting, focusing on simplifying, abstracting and transforming crude data. Which emerged from written notes in the field. Reducing data means summarizing, selecting the main things, focusing on the important things, looking for themes and patterns. 
- Display Data

After all the data has been formatted based on the data collection instrument and has been written (script), the next step is to display the data. In principle, display data is managing semi-finished data that is uniform in written form and already has a clear flow of themes into categories according to themes that have been grouped. Categorizing or coding is the core data of qualitative analysis.

- Withdrawing Conclusions (Verification)

In drawing conclusions in this study will reveal several things the meaning of the data that has been collected. From these data, conclusions will be obtained that are tentative, vague, rigid and dubious, so that verification is needed in these conclusions. Verification is done by looking back at data reduction or data display so that the conclusions drawn do not deviate.

\section{Data validity}

To achieve a level of credibility in this research, several steps can be followed, namely Triangulation, which is checking the correctness of existing data and has been obtainFed by comparing it with data obtained from various other sources regarding the same thing in various phases of field research in a different time. Different and using different methods. Informants of PT Bank XYZ credit card owners and sources (experts in banking)

\section{RESULT AND DISCUSSION}

PT. Bank XYZ in October 1997, established a new division, namely the Card Business Management Division or Card Center. Its first product was XYZ Master Card, followed by XYZ Visa in April 1999. With the issuance of the two types of cards, the cards issued by Bank XYZ as the Credit Card Issuing Bank were complete. In addition, one form of Bank XYZ service for customers convenience in accessing their savings is through a debit card. Cardholders / customers can interact directly by visiting the WalkIn Center (WIC). Currently it can be found in Jakarta, Bandung, Semarang, Surabaya, Denpasar, Medan and Makassar. Currently, XYZ Card Center has 9 Representative Offices located in seven major cities, namely Medan, Palembang, Batam, Bandung, Semarang, Surabaya, Denpasar, Manado and Makassar.

Complaints are often given to company:

- Did not receive billing invoice or billing the bill came after maturing

Many of the customers who have the nature of opportunistic and complain about the delivery of billing bills late, causing customers do not know how many bills and forget the bill, swelling of the bill occurred due to the existing penalty interest, and the customer does not want to pay it.

What has been done by the customer is by calling back the number that often, but is often directed to contact the call center in Jakarta, however The problems that arise when customers contact the call center are credit limitations, and the level of difficulty to connect to the line that has been provided.

For the problem of billing bills that are often late, the bank should do this:

$\checkmark \quad$ Make sure the billing delivery has been received by the recipient or family at home

$\checkmark$ Reconfirmation via telephone to the customer and ask whether it has been received or not, even if you don't meet by telephone with the customer, you can double check the home telephone number and leave a message to the person at home, and never forget to record all activities related to the customer in the system, so that it is easy to recheck another day, and that is evidence that BNI has tried to contact the customer to confirm billing for

- Case Dispute

When a case dispute occurs (a transaction that was not carried out) with late billing bills, many customers take advantage of this condition, for example, when The customer already has a bill in the previous month and then the following month there is a bill dispute, while for the settlement of a case it dispute takes a long time, it could be that it is past the customer's due date, most customers wait for the dispute to finish and then make a payment, when the case is over, the bill has swelled, and customers don't want to $\mathrm{m}$ payment. A case like this will be detrimental to both parties, both from the consumer itself or the company

Dispute is a bit risky, it can be first review how the dispute occurred, back to the original agreement when filling out the credit card form there is a statement where everything that happens to the credit card is the responsibility of the customer, if the dispute transaction is retail, for example shopping in a store but the customer does not admit it, that is still the customer's responsibility, but when the transaction is a transaction such as insurance and travel agents, 
in this case it is better for BNI to tighten cooperation with insurance and travel agents so that they really offer their products properly, not deceiving customers by breaking promises. Choosing a business partner who has full responsibility for solving when a problem occurs, education is not only given to Bank employees, but also to partner employees. Because when the error that occurs is the fault of the insurance and travel agents, the customer only asks PT Bank XYZ which will be held accountable by the customer. Insurance and travel agents provide clear hotlines for complaints.

- Complaint Handling which is complicated According to customers, direct handling to a place or walk in center is the same. Customers are expected to come to the service office where there is only one walk in center (WIC) which is also called customer service in each region, in East Java there is only one at Bank XYZ kedungdoro. When you arrive in Surabaya, it turns out that there is no more handling, and not resolved. When customers who have a high level of activity, they prefer a contact center that is already available with the risk of a long response and completion. However, the Customer is not worried because the customer has contacted and reported it but it is not resolved, therefore the customer does not want to pay the fine.

The results of interviews with customers and employees, both regular staff and leaders, it is known that delays in sending bills sent, annual fees and transactions that are not carried out or disputes are very influential on the existing opportunistic attitude, many of them really. Take advantage of this situation, which will be detrimental to the bank, but in this case how the bank can anticipate and respond to all the problems that exist. If the company is just a little careless, there will be many situations that will be exploited by consumers.

Delivery of bills sent, annual fees and transactions were not carried out or disputes very influential on the existing opportunist attitude, many of them really took advantage of this situation, which would be detrimental to the bank, but in this case how the bank can anticipate and respond to all existing problems. If the company is just a little careless it will be many the situation that the consumer will take advantage of.

Based on interviews that were also conducted with employees, there were several important notes, namely:

- Benefits of Complaining by Coming to the Office

according to employees, when customers come directly to the office is the right choice so that everything is clear, and employees can know how the customer's body language and employees can better know how to solve it rather than via phone. Direct communication with customers in the office tends to be more resolved, customers can complain of all the complaints without having to be chased at a premium rate when making complaints via telephone

- Actions taken by PT Bank XYZ

PT Bank XYZ always tries to evaluate every week on performance of each employee. Evaluating existing problems, including complaints from opportunistic customers and even if PT Bank XYZ is wrong, the Company will apologize and try to resolve everything immediately. Employees will generously apologize for any problems that arise from both the company and the customer and seek solutions in the form of solutions that do not harm both parties. For example, an insurance dispute handling case, in which the customer feels that he does not feel he has accepted the offer of using insurance or credit card, but there is a bill. The risk is that if the good name of the customer as the credit card user is not paid, it will not be well on the check list of Bank Indonesia or what is commonly known as BI Checking, it will be noted that the customer is a bad user and has a bad history at the main bank, namely Bank Indonesia.

From the results of interviews with customer informants and employees and experts, there are 3 similarities that often occur, namely in relation to dispute cases, unpunctual billing arrivals, complicated complaint handling, the following are carried out by:

- Adding free telephone placement points in several areas, so far there is free telephone service at one point, namely at the kedungdoro branch only, customers can use the telephone to contact the Jakarta call center. You can add more free telephone services. In order to make it easier for customers The

- Lack of credit card customer service, if customer service savings exist at each branch, it's different for credit card customer service where there is only one prosperity, namely 
Surabaya at the kedungdoro branch, whether it is better to have additional employees customer service in several more branches, maybe it will increase the cost, but seen from the development of PT Bank XYZ credit cards today, the growing business development is certainly accompanied by maintaining customer satisfaction

\section{CONCLUSION}

Based on the results of research and interviews that have been conducted on Opportunistic claiming customer claiming reviews at PT Bank XYZ card center division (Credit card), several conclusions are obtained, including the following:

- The many complaints that come from opportunistic customers, with all the anger overflowing negative emotions of customers, some still use it because of the elements of need, and convenience.

- The actions taken so far by PT Bank XYZ have been maximized, seeking to evaluate each period the performance of each employee, evaluate existing problems including complaints from opportunistic customers and other customer complaints.

- So far, if the error that has occurred is the fault of the bank, the company will gracefully apologize to the customer and try to prevent the mistake from being repeated.

\section{REFERENCES}

[1] https://infobankstore.com/magazine/detail/2008 /211/infobank-edisi-april-2008

[2] Istanbulluoglu, Leek, \& Szmigin, Beyond exit and voice: developing an integrated taxonomy of consumer complaining behaviour. European Journal of Marketing $(5 / 6), 2017$.

[3] Trovoll, Bard : A dynamic model of customer complaining behaviour from the perspective of service-dominant Logic. European Journal Of Marketing 46(1/2):284-305 European Journal Of Marketing, 2012.

[4] https://infobankstore.com/magazine/detail/2008 /211/infobank-edisi-april-2008

[5] http://www.cnnindoenesia.com) diakses 15 desember, 2019.

[6] Lam, N.W.W., \& Dale, B.G. Customer complaints handling system: Key issues and concerns. Total Quality Management, 10(6), 843-8, 1999.

[7] Mukherjee, A.\& Nath, P, Role of electronic trust in online retailing: A re-examination of the commitment-trust theory. European Journal of Marketing 41, 1173-120, 2003.

[8] Ping, R. A., Jr.The effect of satisfaction and structural constraints on retailer exiting, voice, loyalty, opportunism, and neglect. Journal of Retailing, 69(3), 320$352,1993$.

[9] Simon J.Bell \& James A. Luddngton : Coping With Customer Complaints,Journal of Services, 2006 8: 22, 2006.

[10] Catherine Soanes, Oxford pocket dictionary, $10^{\text {th }}$ Edition, 2005.

[11] Simon J.Bell \& James A. Luddngton Coping With Customer Complaints,Journal of Services, 8: 22,2006.

[12] Simon J.Bell \& James A. Luddngton Coping With Customer Complaints,Journal of Services, 8: 22. 2006.

[13] Kotler, Philip. Marketing Management. $11^{\text {th }}$, Jakarta: Indeks kelompok Gramedia, 2003

[14] Endar Sugiarto. Psikologi Pelayanan Dalam Industri Jasa. Jakarta: Gramedia.1993.

[15] Mukherjee, A.\& Nath, P.: Role of electronic trust in online retailing: A re-examination of the commitment-trust theory. European Journal of Marketing 41, 1173-120, 2003.

[16] Ping, R. A., Jr. The effect of satisfaction and structural constraints on retailer exiting, voice, loyalty, opportunism, and neglect. Journal of Retailing, 69(3), 320-352, 1993.

[17] Yin, Robert K, Studi Kasus: Desain \& Metode, M.Djauzi Mudjakir (penerjemah), PT. Raja Grafindo Persada, Jakarta, 2003.

[18] Yin, Robert K, Studi Kasus: Desain \& Metode, M.Djauzi Mudjakir (penerjemah), PT. Raja Grafindo Persada, Jakarta, 2003. 